\title{
Age and attitude: Changes in cycling patterns of different e-bike user segments
}

\author{
Haustein, Sonja; Møller, Mette
}

Published in:

International Journal of Sustainable Transportation

Link to article, DOI:

$10.1080 / 15568318.2016 .1162881$

Publication date:

2016

Document Version

Peer reviewed version

Link back to DTU Orbit

Citation (APA):

Haustein, S., \& Møller, M. (2016). Age and attitude: Changes in cycling patterns of different e-bike user segments. International Journal of Sustainable Transportation, 10(9), 836-846.

https://doi.org/10.1080/15568318.2016.1162881

\section{General rights}

Copyright and moral rights for the publications made accessible in the public portal are retained by the authors and/or other copyright owners and it is a condition of accessing publications that users recognise and abide by the legal requirements associated with these rights.

- Users may download and print one copy of any publication from the public portal for the purpose of private study or research.

- You may not further distribute the material or use it for any profit-making activity or commercial gain

- You may freely distribute the URL identifying the publication in the public portal

If you believe that this document breaches copyright please contact us providing details, and we will remove access to the work immediately and investigate your claim 


\section{Age and attitude: Changes in cycling patterns of different e-bike user segments}

\section{Sonja Haustein \& Mette Møller}

To cite this article: Sonja Haustein \& Mette Møller (2016): Age and attitude: Changes in cycling patterns of different e-bike user segments, International Journal of Sustainable Transportation, DOI: 10.1080/15568318.2016.1162881

To link to this article: http://dx.doi.org/10.1080/15568318.2016.1162881

Accepted author version posted online: 23

Mar 2016.

Submit your article to this journal $₫$

III Article views: 34

Q View related articles $₫$

View Crossmark data 


\title{
ACCEPTED MANUSCRIPT
}

Changes in cycling patterns of e-bike segments

Age and attitude: Changes in cycling patterns of different e-bike user segments

Sonja Haustein* and Mette Møller

Danmarks Tekniske Universitet (DTU), Kgs. Lyngby, Denmark

*CONTACT Sonja Haustein sonh@transport.dtu.dk Danmarks Tekniske Universitet (DTU), DTU Transport, Kgs. Lyngby, Denmark.

\begin{abstract}
The use and purchase of electric bicycles (e-bikes) is emerging in many countries. Existing knowledge about changes in cycling patterns and car replacement after gaining e-bike access is limited and partly contradictory. Based on an online survey among e-bike users in Denmark $(N=$ 427), this study looked into these effects by differentiating between different segments of e-bike users. We distinguished four age groups as well as three segments based on cycling attitudes and motives for the use and purchase of e-bikes: (1) enthusiastic e-bikers who showed the most positive attitudes towards e-bikes and mainly bought an e-bike to increase cycling frequency; (2) utilitarian e-bikers who already cycled regularly before having access to an e-bike and used the e-bike particularly for practical purposes and to reduce travel time; (3) recreational e-bikers who were very positive about e-bike use but used it less regularly and mainly for long-distance recreational trips. Enthusiastic e-bikers reported the highest increase in overall cycling. Half of the enthusiastic e-bikers agreed that they bought the e-bike to replace a car. Differences between the four age groups were less pronounced. Nevertheless, we found that e-bike access decreased age differences in self-reported cycling frequency, whereas it increased differences in selfreported distances. Measures to increase e-bike use should primarily focus on potential
\end{abstract}




\section{ACCEPTED MANUSCRIPT}

enthusiastic e-bikers. Possible interventions include promotional campaigns at workplaces, intended to address not only instrumental but also affective motives of e-bike use.

\section{KEYWORDS}

e-bike; segmentation; attitude; cycling; age; mobility

\section{ARTICLE HISTORY}

Received 26 May 2015 Revised 28 February 2016 Accepted 3 March 2016 


\section{ACCEPTED MANUSCRIPT}

1. Introduction

Electric bikes (e-bikes) are an emerging vehicle type in many countries. While e-bikes are already a mainstream transport mode in China, they account for more than $15 \%$ of total bicycle sales in Switzerland and the Netherlands (Fishman \& Cherry, 2015), and about $12 \%$ in Austria and Germany (VSSÖ, 2015; ZIV, 2015), which place them as the four leading e-bike countries in Europe. While women, older adults, and people with physical limitations were at first assumed to be the main target groups for use of e-bikes (Dill \& Rose, 2012), this has proved to be a too narrow definition, and e-bike users in particular disagree with this assumption (Preissner et al., 2013). Mercat (2013) found that middle-aged persons are particularly attracted by e-bikes, most of them having a driver's licence and good access to a car (Hiselius \& Svenssona, 2014). In the Netherlands, $10 \%$ of middle aged persons owned an e-bike in 2012 , the same percentage as in the age group above 60 years of age (Fietsberaad, 2013). In most studies, independent of origin, persons with higher income and/or education are overrepresented among e-bike users (e.g. Cherry \& Cervero, 2007; Johnson \& Rose, 2013; MacArthur et al., 2014; Popovich et al., 2014; Preissner et al., 2013). In terms of gender distribution, studies from western countries identified more men than women among e-bike users/owners (e.g. Johnson \& Rose, 2013; Hiselius \& Svenssona, 2014; MacArthur et al., 2014; Popovich et al., 2014), while genders are more equally distributed in China (e.g. Cherry \& Cervero, 2007; Weinert, Ma, Yang, \& Cherry, 2007).

\subsection{Impact on mobility}

In accordance with increased distribution of e-bikes, also emerging is research about the possible impacts of e-bike use in terms of mobility, environment, health, and safety (see Fishman \& 


\section{ACCEPTED MANUSCRIPT}

Cherry (2015) for a review). Important questions in relation to the different effects include: Does, and how does, access to an e-bike change mobility behaviour? Are additional trips conducted or previous trips replaced? And, in the case of trips replaced, for which purposes are they replaced, and by which transport modes were they formerly conducted?

Existing studies do not yet provide definite answers to these questions. Studies from China, where e-bikes are already a mainstream mode, find different replacement rates for other transport modes, reaching from a substitution rate of about $60 \%$ of bicycle trips (Weinert et al., 2007) to a predominant replacement of bus trips (Cherry \& Cervero, 2007), probably depending on the quality of the available public transport service. Also European studies come to different results: While a study from the Netherlands concludes that mainly trips by conventional bikes are replaced by e-bikes (Engelmoer, 2012), a Swedish study finds that about half of the reported ebike trips were previously conducted by car and only around $20 \%$ by conventional bike (Hiselius \& Svenssona, 2014). A Norwegian study found that access to an e-bike increased the share of bike trips from $28 \%$ to $48 \%$ (Fyhri \& Fearnley, 2015).

While some studies find that e-bikes are mainly used for commuting (e.g., MacArthur et al., 2014), others find a predominance of leisure trips (Wolf \& Seebauer, 2014) or mixed purposes (Fyhri \& Fearnley, 2015). These contradictory results may reflect actual differences between countries and/or cities with differing cycling cultures (cf. Aldred \& Jungnickel, 2014; Carstensen \& Ebert, 2012), and/or the results may be attributed to different methods of data collection, leading to the inclusion of different user groups, for example older or younger e-bike users who might use the e-bike in different ways within each study area. A closer look at the cycling 


\section{ACCEPTED MANUSCRIPT}

patterns among different segments of e-bike users is therefore needed to provide more insight into the various impacts of e-bike use.

\subsection{Market segmentation in the transport sector}

Road users can be divided into segments in many different ways, and deciding which way is the most appropriate highly depends on the purpose of application (cf. Haustein \& Hunecke, 2013). In a segmentation approach based on travel behaviour, Heinen, Maat, and van Wee (2011), for example, divided cyclists into three groups: non-cyclists, full-time cyclists, and part-time cyclists. Such behaviour-based segmentations fulfil a descriptive function but do not per se provide information about the underlying processes determining behaviour. A segmentation based on socio-demographic characteristics directly allows for some conclusions with regard to specific mobility needs as age, gender, occupation, household structure, ethnicity, and income are relevant determinants of mode choice. Different life stages and life styles have been differentiated by the combination of household variables, age, and occupational status (e.g., Hildebrand, 2003; Ryley, 2006; Salomon \& Ben-Akiva, 1983). While segmentations based on socio-demographic variables allow for an easy identification of segment members who can then be targeted according to their specific needs, the underlying factors (such as age or gender) cannot be changed by interventions - a challenge that can be overcome by segmentations based on attitudinal factors. In the last decade, attitudinal segmentations in the transport sector have increased considerably (e.g., Anable, 2005; Hunecke, Haustein, Böhler, \& Grischkat, 2010; Li, Wang, Yang, \& Ragland, 2013; Pronello \& Camusso, 2011) and have shown to explain more variance of travel mode choice than socio-demographic segmentations (Hunecke et al., 2010; Hunecke \& Schweer, 2006). In addition, the attitudinal profiles can be used to develop targeted 


\section{ACCEPTED MANUSCRIPT}

services, products, and campaigns to facilitate modal shifts. Attitudinal segmentations are often based on psychological theories, particularly the Theory of Planned Behaviour (Ajzen, 1991), and thereby implicitly contain assumptions about how the respective behaviour within a segment can be changed. The emphasis on behaviour change is much more explicit in segmentations based on the Transtheoretical Model of Behaviour Change (TTM, Prochaska \& DiClemente, 1983). Here it is assumed that people go through a series of stages (precontemplation, contemplation, preparation, action and maintenance) before they voluntarily change their behaviour. This approach, which originates from health psychology, has been applied to both the reduction of car use (Bamberg, Fujii, Friman \& Gärling, 2011) and promotion of cycling (Gatersleben \& Appleton, 2007; Nkurunziza, Zuidgeest, \& Van Maarseveen, 2012) and stresses the need for stage-specific interventions when wanting to achieve behavioural change. Finally, different groups of factors can also be mixed in order to identify relevant target groups, as for example done by Dill and McNeil (2013), who differentiated between four types of (potential) cyclists based on their comfort level with cycling, their interest in cycling as transportation, and their physical ability to cycle.

\section{The present study}




\section{ACCEPTED MANUSCRIPT}

Based on attitudinal segmentation the purpose of the current study was to identify distinct subgroups among e-bike users. We expected that motivations and attitudes with regard to e-bike use are more relevant than is age for cycling patterns before and after access to an e-bike as well as for satisfaction with use of an e-bike. Thus we expected a higher number of statistically significant differences between the identified attitudinal segments than between age groups with regard to cycling patterns and e-bike satisfaction. We further assumed that the resulting attitudinal segments could be used as a starting point for promoting e-bike use in a targeted and thereby more effective way including information on in which segment the greatest environmental effects are achievable in terms of a modal shift from car to e-bike.

Our selection of relevant motivations for e-bike use was inspired by results from previous studies. As in the case of car use (e.g. Anable \& Gatersleben, 2005; Steg, 2005), we expected that not only instrumental motives but also affective motives are relevant for e-bike use and purchase. In terms of instrumental motives, facilitating cycling under difficult environmental conditions (e.g. hilly ground, wind and rain) and with physical limitations has been found to be relevant (Popovich et al., 2014), enabling to maintain or increase speed with less effort (Johnson \& Rose, 2013; MacArthur et al., 2014). In North America and Australia, the possibility to replace a car has been identified as a relevant purchase motivation (MacArthur et al., 2014; Johnson \& Rose, 2013; Popovich et al., 2014). With regard to affective motives, e-bike users especially emphasised the fun while riding an e-bike due to increased speed and acceleration (Popovich et al., 2014; Preissner et al., 2013). We expected that, beyond that, a positive attitude towards cycling is of utmost importance. 


\section{ACCEPTED MANUSCRIPT}

In the following section, we describe the data collection and the content of the questionnaire used in the present study. In the analysis part, we describe how we defined the age groups and developed the attitudinal segments. In Section 3, results are reported, and in Section 4 we discuss the differences found between attitudinal segments and age groups, derive ideas for targeted interventions, and suggest improvements for future studies.

\section{Method}

\subsection{Data collection}

Data were collected by means of an internet survey conducted by the market research company Megafon on behalf of the Danish Road Safety Council (Rådet for Sikker Trafik) using Megafon's own panel and an additional panel (YouGov, see https://yougov.co.uk for details). Members of Megafon's panel are continuously recruited by telephone in connection with population-based surveys using the last-birthday selection method. Respondents are randomly drawn from a database including all landline and mobile numbers in Denmark.

In total, 568 panel members with internet access and who had previously stated that they had used an e-bike ${ }^{1}$ on a regular basis over a period of at least one month were asked to participate in the survey. The target group was contacted by e-mail and could fill in the internet survey any time during a period of three weeks in October 2014. All in all, 427 (75\%) persons filled in a questionnaire that could be used in this study; $23 \%$ did not answer the request, and $2 \%$ of the returned questionnaires could not be used.

\footnotetext{
${ }^{1}$ In Denmark, e-bikes are electric powered bicycles that require pedal assistance and pedalling is supported up to $25 \mathrm{~km} / \mathrm{h}$ (also referred to pedelecs in other countries).
} 


\section{ACCEPTED MANUSCRIPT}

\subsection{Questionnaire}

The questionnaire asked how long participants have had access to an e-bike (6-point scale from "up to 1 week" to "more than one year") and in what way they had access to an e-bike ("e-bike owner"; "shared e-bike in the household"; "access through others (e.g. workplace, friends)"; "access for a limited period e.g. through participation in a trial"; "other"). With regard to e-bike use cycling frequency was assessed on a 7-point frequency scale reaching from "daily" to "never" and distances typically covered on a day the e-bike was used (8-point scale from "did not cycle" to "more than $20 \mathrm{~km}$ "). Cycling frequency and distances covered were also assessed for the use of a conventional bicycle both before and after access to an e-bike. Included cycling attitudes and motivations for buying and using an e-bike are shown in Table 1 and Figure 1. Participants were further asked if the e-bike met their expectations and to what extent the e-bike replaced trips by other transport modes (conventional bike, walking, bus, trains/metro, and car). In all cases the same 5-point Likert scale was used ( $1=$ "totally disagree" -- $5=$ "totally agree"). Background variables included age, gender, income, level of education, and place of residence (municipality). The questionnaire further included questions regarding the purchase of the e-bike and safety-related aspects, which were, however, not within the scope of this paper.

\subsection{Analysis}

The sub-groups of e-bike users identified based on age or attitude were the basis of all further analyses. In the following we first describe how we identified these groups and then which analysis we conducted to compare the different groups.

\subsubsection{Age groups}




\section{ACCEPTED MANUSCRIPT}

The age groups used in this paper were created roughly following a life stage approach that included the following stages: young adulthood, finalising education/starting career; pre family/starting family phase (19--35); middle adulthood, family \& career phase (36--55); later adulthood, pre-retirement/empty-nest phase (56--65); old adulthood, retirement phase (>65).

\subsubsection{Segments based on attitudinal factors}

The attitudinal segments were created in two steps: (1) a principal component analysis and (2) a cluster analysis. A principal component analysis with varimax rotation was carried out to reduce the number of items to their underlying dimensions. Retaining only factors with eigenvalues greater than one, a 4-factor solution was obtained, which explained $62.4 \%$ of the variance. Table 1 presents the loadings of the single items on the four factors. On factor 1 , items that relate to facilitating cycling through the use of an e-bike have the highest loadings. Factor 2 covers different affective and instrumental motives of e-bike use. The motives referring to physical activity, environment, and price are, however, not specific to e-bikes but could be related to conventional bikes to the same extent. Therefore, we interpret this factor as indicative of a general positive attitude towards cycling as expressed in the item "I use the e-bike because I like cycling." Factor 3 relates to excitement specifically resulting from e-bike use, particularly in relation to the higher speed and acceleration as compared to a conventional bike. Finally, two items have substantial loadings on factor 4 . One item relates to e-bikes being quicker than other transport modes and the other item to using it for practical purposes, such as shopping and delivering/picking up children. In contrast to the first factor, the specific advantage of the e-bike in relation to this factor is not the longer distances that can be covered as compared to a 


\section{ACCEPTED MANUSCRIPT}

conventional bike but the possibility to transport persons and goods quicker as compared to other transport modes.

Based on the items with the highest loadings on each factor, mean scales were calculated. Only one item had a comparable low loading and loaded on two factors (item 8). As it clearly belonged, in terms of content, to the e-bike excitement factor, we added it to this factor, where it actually increases the internal consistency (whereas it weakened the internal consistency when added to the facilitating cycling scale). With Cronbach's alpha showing values around .7, the four mean scales had acceptable internal consistencies.

As the second step towards the attitudinal segmentation, cluster analyses were conducted based on the k-means algorithms, which is the "most widely used partitional clustering algorithm in practice" (Wu et al., 2008; p. 9). Analyses resulting in two to five clusters were calculated and the interpretability of the different cluster solutions was used as the main criterion for choosing the number of clusters. The two-cluster solution included one type with highly positive agreement to all factors and a second cluster with lower agreement, especially with regard to facilitating cycling for everyday life (transport of goods/children). The three-cluster solution further distinguished this second type, revealing two different profiles. In contrast, the fourcluster solution added no new qualitative profile but revealed the same clusters as the threecluster solution with the only difference that the one cluster (Cluster 1 in the three-cluster solution) appeared twice, once with a higher and once with a lower agreement to the different factors. We additionally compared how good the different cluster solutions differentiated between e-bike cycling patterns by calculating differences in cycling frequency and distances between the clusters by K-W-tests and by comparing the results of the different solutions. 


\section{ACCEPTED MANUSCRIPT}

As Table 2 reveals, the two-cluster solution could only differentiate significantly between cycling frequency while all other solutions also differentiated significantly $(p<.05)$ with regard to distances. The improvements of the four and five-cluster solutions as compared to the threecluster solution were not so big that they justified a distinction of more than three clusters. We thus stuck to the more parsimonious three-cluster solution. We finally checked the results of different initialisations of k-means. All tested initialisations lead to similar cluster profiles, differing only in the exact number of cluster members. The distances between the final cluster centres were 2.18 (cluster 1-cluster 2), 2.42 (cluster 1-cluster 3), and 2.41 (cluster 2-cluster 3), thus cluster 1 and 2 were a bit closer to each other. Five persons had an ambiguous cluster allocation as they had almost equal distances to two cluster centres (difference smaller than 0.1), in 80 cases the difference to the second closest centre was between 0.1 and 0.5 longer than to the own cluster, in the remaining 347 cases $(81 \%)$, the differences were above 0.5 . The cluster profiles are described in more detail in Section 3.3.

\subsubsection{Comparison of segments and segmentation approaches}

We compared cycling patterns, replacements of trips by other modes, and e-bike satisfaction for people belonging to different age groups and attitudinal segments based on ANOVAS (including post hoc tests; Bonferroni) and Kruskal-Wallis-Tests (K-W-test) depending on the scale of measurement. We used Wilcoxon signed-rank test for related samples to identify differences within the segments in relation to cycling before and after access to an e-bike and paired samples t-tests to identify differences within the groups in relation to the replacement of trips by different transport modes. In addition, the identified user segments were compared by demographic variables $\left(\chi^{2}\right.$-test). 


\section{ACCEPTED MANUSCRIPT}

\section{Results}

In Section 3.1, the sample is described based on background variables, followed by some descriptive key results for the total sample (Section 3.2). In Section 3.3, the profiles of the user segments are described. Cycling patterns and e-bike satisfaction are then compared between user segments and age groups in Section 3.4.

\subsection{Sample description}

All in all, 427 persons were included in this survey. Table 3 shows the age and gender distribution of the sample and the level of education, and compares it with the weighted sample based on the knowledge about e-bike users in the complete panel, their age, gender, education and regional distribution, extrapolated to the adult population in Denmark. It shows that in our sample e-bike users in the youngest and oldest age groups are underrepresented, whereas e-bike users between 60 and 69 years of age are especially overrepresented. In addition, women are slightly underrepresented, whereas people with higher education are overrepresented. Comparing these data with the age and gender distribution in the complete adult population of Denmark (Statistics Denmark, 2015), we found that e-bike users are a bit more often female, more often belong to the age groups above 50 years and are less often found among people under the age of 40 years and slightly better educated.

\subsection{E-bike use, motivations, and satisfaction}

While a precondition to take part in the survey was to have been using an e-bike for a period of at least one month, the majority of the participants have had access to an e-bike for more than one year (67\%); $76 \%$ owned a personal e-bike, $13 \%$ had access to an e-bike in the household, 


\section{ACCEPTED MANUSCRIPT}

and $11 \%$ had access to an e-bike through other sources, e.g. the workplace. Before having access to an e-bike, $44 \%$ of participants cycled several times a week, while $26 \%$ cycled less than monthly. When having access to an e-bike, cycling frequency on a conventional bike decreased, while the e-bike was used by $74 \%$ of participants several times a week, and only by $2 \%$ less than monthly.

Most participants agreed to having bought or tested an e-bike to be able to cover longer distances; to cycle longer without getting exhausted; and to cycle more often or to start cycling (see Figure 1). While the fun riding on an e-bike also played a relevant role, replacement of a car (or second car) was less important. The high standard deviation for this statement can be explained by the fact that $21 \%$ totally agreed that they had bought an e-bike to replace a car in the household, while 38\% totally disagreed. Regarding e-bike use, the highest percentage of participants agreed to using the e-bike because they liked cycling; to get exercise; because it is cheaper than other modes; or because of environmental reasons. In contrast, the majority disagreed with the statement that they would use an e-bike because of lacking access to other transport modes. Here we also found a high standard deviation because $66 \%$ totally disagreed with this statement, while 9\% totally agreed. Figure 1 displays the means and standard deviations for all items, sorted by level of agreement.

With regard to replacement of trips by other modes, $64 \%$ agreed that they used an e-bike on trips for which they would otherwise have used a conventional bike, while $49 \%$ agreed that they used it on trips for which they would otherwise have used a car (bus: 48\%; walking: 33\%; train/metro: $26 \%)$. 


\section{ACCEPTED MANUSCRIPT}

When asked if the e-bike met their expectations, $91 \%$ of the participants agreed that their expectations were met (64\% totally agreed, $27 \%$ agreed). People were asked in an open question

to specify to which extent expectations were not met (if relevant). The answers were categorised. Due to the high overall satisfaction, only 32 answers were given. Most of these (34\%) fell into the category "battery", and referred to the range or life of the battery. Nearly one fifth (19\%) of the answers referred to the e-bike being too heavy, which is found especially problematic when the battery is not working, and the same percentage $(19 \%)$ referred to the maintenance of the ebike as requiring too much effort or being too expensive.

\subsection{Profiles of attitudinal e-bike segments}

As described in Section 2.3.2, three e-bike segments were identified based on cluster analysis. Table 4 provides the means and standard deviations for the three clusters with regard to the four factors that were used for clustering. ANOVA results show that the clusters differ significantly with regard to all four factors. The first segment, the so-called enthusiastic e-bikers, appreciate the e-bike for facilitating cycling both with regard to distance/frequency as well as speed and practical purposes. Their overall attitude to cycling is very positive but to the same extent they appreciate the e-bike for the increased speed and fun as compared to a conventional bike (e-bike excitement).

Members of the second segment, the so-called utilitarian e-bikers, are less prone to use the ebike to increase the amount of cycling (distance/frequency). They use it especially to optimise their daily transport when using it for practical purposes, such as picking up children or shopping. Increased speed is mostly appreciated for practical reasons and seen as an advantage compared to other transport modes, but less as a gain in itself as it is for the other e-bike 


\section{ACCEPTED MANUSCRIPT}

segments, as shown by the relative low importance of e-bike excitement. Actually, only $41 \%$ totally agreed that they rode faster than on a conventional bike (vs. $83 \%$ in the enthusiastic ebike segment and $75 \%$ in the third segment, see next paragraph), which may indicate that they already used the conventional bike with comparable high speed and regarded cycling per se as a fast transport mode as compared to other modes.

Members of the third segment, the recreational e-bikers, strike out for being less prone to use the e-bike for practical purposes, while they especially appreciate being able to cycle more and longer as well as the excitement gained from increased speed. In that respect their profile is similar to that of the enthusiastic e-bikers.

In post-hoc comparisons (Bonferroni corrected) all clusters differ significantly from each other with regard to all factors $(p<.001)$, with one exception: utilitarian and recreational e-bikers do not differ from each other with regard to cycling attitude $(p=.23)$, while both groups differ from enthusiastic e-bikers in that respect.

\subsection{Cycling patterns}

\subsubsection{Cycling frequency and distances}

Table 5 displays the cycling frequency for the attitudinal segments and age groups before and after having access to an e-bike. The percentage of people who cycle on a conventional bike on a daily basis decreased in all segments by approximately $50 \%$ and the decrease in cycling frequency is significant within all segments (Wilcoxon test, all $p<.001$ ). However, when comparing cycling frequency on a conventional bike before having access to an e-bike with cycling frequency on an e-bike after access, we find a significant increase in all groups 


\section{ACCEPTED MANUSCRIPT}

(Wilcoxon test; enthusiastic e-biker and recreational e-biker: $p<.001$ ), though less pronounced for utilitarian e-bikers $(p<.05)$.

Almost 70\% of utilitarian e-bikers used the conventional bike several times a week before having access to an e-bike. With access to an e-bike, they used the e-bike at about the same rate as enthusiastic-e-bikers, but more often still used their conventional bike in addition. Recreational e-bikers used both types of bikes less frequently.

The user segments differed significantly regarding the frequency of the use of the conventional bike before and after e-bike access as well as regarding e-bike use. The different age groups only differed significantly in the use of the conventional bike before having access to an e-bike -showing decreasing frequency with increasing age. The results thus indicate that the e-bike eliminates age differences in cycling frequency.

In Table 6, distances covered by conventional bikes and e-bikes are shown separated by user segment and age group. All segments significantly reduced the distances typically covered on a conventional bike after having access to an e-bike (Wilcoxon test, all $p<.001$ ), while we find a significant increase in distances within each segment, when distances on a conventional bike before e-bike access are compared to distances covered on an e-bike (Wilcoxon test; enthusiastic e-biker and recreational e-biker: $p<.001$ ); the difference is again less pronounced for utilitarian e-bikers $(p<.05)$. The segment of recreational e-bikers have the highest share of members who typically used the e-bike for distances longer than $20 \mathrm{~km}$. Utilitarian e-bikers covered the least distances by e-bike but the most distances by conventional bike, also after having access to an ebike. Again, the user segments differ significantly in e-bike use as well as in the use of the conventional bike before and after having access to an e-bike (see Table 6). In the case of age 


\section{ACCEPTED MANUSCRIPT}

groups, we find that age is only relevant for the distances covered by e-bike. In that sense, ebikes seems to increase the age differences in distances covered by bike. More than half of the persons aged 19--55 travelled more than $10 \mathrm{~km}$ per day by e-bike.

\subsubsection{Replacement of trips by other modes}

All segments agreed most to their using the e-bike to replace trips by a conventional bike, followed by car trips (see Table 7). While enthusiastic e-bikers agreed to having replaced trips by all modes more than did the other segments, there were some differences between the latter: utilitarian e-bikers used the e-bike more often instead of public transport, whereas recreational ebikers used it more often instead of individual modes, especially instead of a conventional bike or a car. In post-hoc tests (Bonferroni corrected), it was, however, only the enthusiastic e-bikers who differed significantly from utilitarian e-bikers in terms of a higher replacement of walking $(p<.001)$ and from both segments with regard to the replacement of all other transport modes $(p$ $<.05)$. When looking at differences within the clusters and comparing replacement of trips by car and conventional bike, we find that recreational e-bikers report significantly higher replacement of bike trips as compared to car trips (paired t-test, $t(111)=-.90, p=.005$ ), while the difference is not significant for utilitarian e-bikers, $t(111)=-.99, p>.10$, and only tendentiously significant for enthusiastic e-bikers, $t(111)=-1.95, p=.053)$.

Half of the enthusiastic-e-bikers agreed that they bought an e-bike to replace a car in the household, while the same was true for $32 \%$ of the utilitarian e-bikers and only $23 \%$ or the recreational e-bikers, $F(2,416)=12.45, p<.001$. In post-hoc tests, enthusiastic e-bikers differed significantly from utilitarian e-bikers $(p<.05)$, and from recreational e-bikers $(p<.001)$. 


\section{ACCEPTED MANUSCRIPT}

When looking at age groups, the differences were much less pronounced. The only two significant results regarded the replacement of a car in the household, $F(2,412)=4.42, p<.01$, where 19--35-year-olds agreed more than all other groups (post-hoc tests, $p<.01$ ) and the replacement of walking trips $(F(2,416)=5.86, p<.01)$, where the oldest age group differed from the two youngest groups by a higher replacement $(F(2,416)=5.86, p<.05)$.

\subsection{E-bike satisfaction}

Enthusiastic e-bikers agreed most $(M=4.74 ; S D=0.52)$, followed by recreational e-bikers $(M=$ 4.39; $S D=0.98)$ and then utilitarian e-bikers $(M=4.14 ; S D=0.89)$, that the e-bike fulfilled their expectations, $F(2,425)=22.29, p<.001$. Enthusiastic e-bikers differed significantly from the other two segments in post-hoc tests $(p<.001)$. Asked to what extent expectations were not met, the enthusiastic e-bikers mentioned the least problems: only three of 201 users reported something that did not meet their expectations. For utilitarian e-bikers, maintenance was the biggest problem, as mentioned by $4 \%$ of the group members, followed by the too low speed of ebikes (as compared to conventional bikes), as mentioned by 3\%. For recreational e-bikers, the battery was the biggest problem (mentioned by $6 \%$ ), followed by the e-bike's weight (4\%). The free answers reflect the profiles of the segments, putting emphasis either on speed and functioning in everyday life, in the case of utilitarian e-bikers, or distance in the case of recreational e-bikers.

When looking into the satisfaction in different age groups, we find that the groups do not differ significantly as to what extent expectations were met, $F(3,423)=0.87, p>.10$. In the case of open answers, we find that "weight" is especially mentioned in the oldest group (by 4\%), 


\section{ACCEPTED MANUSCRIPT}

"battery" in the middle age group (36--55 years; by 4\%), and "low speed" in the youngest group (by $3 \%$ ).

\subsection{Demographic differences}

Table 8 shows demographic differences between the three attitudinal segments. The age differences between the segments are not very pronounced and only tendentiously significant $(p$ $<.10)$. Persons in the utilitarian e-biker segment are slightly overrepresented in the age groups in which it is most likely to have small children (30--55), while they are slightly underrepresented in the group beyond normal retirement age $(>65)$. Recreational e-bikers are underrepresented in the youngest age group (19--35). Also gender differences are rather small, with women being slightly overrepresented in the enthusiastic e-biker segment and men in the segment of utilitarian e-bikers. With regard to education, the lowest percentage of people with only basic education was found in the enthusiastic e-biker segment, with $24 \%$ having a university education. While utilitarian e-bikers are overrepresented in Copenhagen, recreational e-bikers are overrepresented outside the capital city.

\section{Discussion and conclusion}

At the overall level, the results of this study indicate that e-bike access contributes to an increase in cycling. Inconsistent results regarding the mobility effects of e-bike access from previous studies may partly be explained by differences in the countries' predominant mobility culture: In countries characterised by a cycling culture, such as Denmark and The Netherlands (Carstensen \& Ebert, 2012; Pucher \& Buehler, 2008), one may expect that higher shares of existing cycling trips are optimised rather than newly conducted, because a higher percentage of the population is already cycling. This is supported by our results as we found a higher replacement of trips 


\section{ACCEPTED MANUSCRIPT}

formerly conducted by conventional bike as compared to countries with no explicit cycling culture, such as Sweden (Hiselius \& Svenssona, 2014). Nevertheless, the overall cycling rates before and after access to an e-bike increased, as also trips formerly conducted by other modes, especially by car, were replaced. At the same time, the results show that e-bike access may also inspire persons who previously did not cycle to become active participants in the existing cycling culture: While $26 \%$ of the participants cycled less than monthly on a conventional bike before having e-bike access, only $2 \%$ cycled less than monthly on an e-bike. It is also remarkable that $37 \%$ of the participants bought an e-bike with the purpose to replace a car in the household; though, in North America and Australia the motivation to replace car trips seems to play an even more important role as mentioned by approximately 60\% of e-bike users (Johnson \& Rose, 2013; MacArthur et al., 2014).

As hypothesised, we found a higher number of statistically significant differences in cycling patterns and e-bike satisfaction between attitudinal segments than between different age groups. This shows that the specific motivation to use an e-bike, and the users' general cycling attitudes, are more relevant than age for cycling patterns and achievable behavioural changes. Yet, a more elaborate socio-demographic segmentation -- taking employment status and number of children into account -- might have better reflected different life-stages than did the segmentation based solely on age. It might also have led to greater differences between the sub-groups. However, as the available data did not allow for that, it should be considered in future studies. Still, the agebased grouping revealed some interesting results: We found that after getting access to an e-bike, age-differences in relation to cycling frequency decreased, whereas age-differences in terms of cycling distances increased. This may indicate that older people use the e-bike more often to take 


\section{ACCEPTED MANUSCRIPT}

up cycling (again), whereas younger people use it to increase the distances travelled by bike.

This is tendentiously supported by the age differences in the attitudinal segments, where younger people are more often among the utilitarian e-bikers, and older people among the recreational ebikers. It is further supported by our findings that older people more often replace walking trips while younger people more often replace car trips. These results indicate that e-bike use among younger people mainly has positive environmental effects, whereas for older people it increases mobility options and thereby contributes to their health and well-being (Haustein \& Siren, 2015; Siegrist \& Wahrendorf, 2009).

\subsection{Targeted interventions addressing e-bike user segments}

When intending to promote e-bikes to decrease car use, increase health, well-being and mobility options, it is advisable to focus on those target groups in which most of these positive effects are achievable.

Focussing on car use reduction, persons with a profile similar to enthusiastic e-bikers should be targeted with priority, as this segment shows the greatest increase in daily cycling. In many cases they probably made a major change in their every-day lives, such as using the e-bike to get to work instead of the car. This assumption is supported by the fact that half of them replaced a car in the household with an e-bike. Moreover, this segment includes a slightly higher share of men, persons in family age, and persons living in the capital of Denmark, which fits with the typical profile of bike commuters (Hansen \& Nielsen, 2014). Measures to attract people with such a profile could include "Test an e-bike" promotions at workplaces, which should not only focus on the device's practical aspects but especially on its positive affective aspects by giving people the opportunity to directly experience the increased speed and acceleration of an e-bike. When 


\section{ACCEPTED MANUSCRIPT}

designing such trials, one should though be aware of safety-related aspects and especially to give testers the opportunity to get used to the e-bike before cycling in demanding traffic situations (Haustein \& Møller, 2015).

The direct environmental effect of e-bike use among people with a profile similar to the utilitarian e-bikers is probably lower, as they were already active cyclists before having access to an e-bike. However, the e-bike probably facilitates coping with everyday life and might prevent a (later) shift from bike to car. Here, targeted measures could include promotional activities at kindergartens and shopping centres, focusing more on instrumental than affective aspects such as saved travel time and effort. One should, however, not promise too much, as the results indicate that expectations of utilitarian e-bikers with regard to increased speed were not always met, and travel satisfaction is known to influence mode choice (Taniguchi, Grääs, and Friman, 2014). The lower satisfaction of utilitarian e-bikers indicates that former non-regular cyclists profit more from e-bike access than do people who are used to cycling on a daily basis. It might, however, also be related to the lower distances of trips conducted by utilitarian e-bikers, where time savings are harder to achieve. Thus, more knowledge on the trip characteristics of utilitarian ebikers and on the specific conditions under which they choose e-bikes over conventional bikes is required.

Regarding recreational e-bikers, the e-bike has probably the least positive environmental effects, as indicated by the lowest car-replacement rate. However, as the health benefits of active transport are indisputable (e.g. Rabi \& Nazelle, 2012), it might have some positive health effects through usage for recreational trips. From an environmental perspective, a specific promotion of 


\section{ACCEPTED MANUSCRIPT}

the e-bike to this group (e.g. in the form of e-bike rentals close to recreation areas) seems least relevant.

\subsection{Limitations and future research perspectives}

The sample size and sample composition, with the oldest and especially the youngest age groups being underrepresented and higher educated persons being overrepresented, can be regarded as limitations of this study. However, as age and education are only weakly related to the attitudebased users segments, we do not expect age to have a relevant effect on the results in relation to the user segments. Nonetheless, having had more people in the youngest age group would have allowed creation of a youngest age group with a lower age limit, which might have increased the age differences identified in this study. Yet, especially in regard to satisfaction with the e-bike, the non-existing difference between age groups undermines the idea that older people are the only relevant target group for e-bikes and stresses the need for targeted measures across age groups.

This study is, to the best of our knowledge, the first study that segmented e-bike users based on attitudinal factors and thereby increased understanding of the different attitudes and motivations that underlie e-bike use. However, the possibilities to include relevant motives for e-bike use and purchase were restricted and leave room for improvements in future studies. The inclusion of factors that account for a general openness to technological innovation may lead to a more differentiated segmentation, which would also provide further information for the marketing of e-bikes. Also a factor accounting for perceived constraints in relation to personal living circumstances, including family and household responsibilities (Pooley et al., 2013; Haustein \& Hunecke, 2007), could improve the understanding of the motivations for e-bike use and in 


\section{ACCEPTED MANUSCRIPT}

addition could probably further clarify the differences between utilitarian e-bikers and the other two segments. Finally, additional symbolic-affective motives of cycling -- such as perceiving cycling as physically/mentally relaxing, perceiving privacy and autonomy as well as social norms, which are found to be relevant factors for conventional cycling (Hunecke et al., 2007; Heinen et al., 2011; Pooley et al., 2013) -- also appear to be promising additions to future surveys on e-bike use. This is supported by a recent study by Rudolph (2014), which shows that mobility segments based on symbolic-affective attitudes in relation to different transport modes (e.g. "Autonomic car enthusiasts" or "Status-conscious motorists") differ in their e-bike use and purchase.

The results of this study are based on self-report data and may thus be biased by factors such as social desirability (Lajunen \& Summala, 2003). Particularly in case of people who have had access to an e-bike for a longer period, the retrospectively reported cycling frequency before ebike access may additionally be subject to memory bias and/or hindsight bias (Roese \& Vohs, 2012). To confirm and specify the assumptions of this study, especially with regard to environmental impacts, actual cycling behaviour (e.g. collected by specific apps when cycling) before and after e-bike access should be collected in future studies. In addition, it would be highly relevant to learn more about the potential of e-bikes to decrease older people's unfulfilled mobility wishes and increase their health and well-being.

\subsection{Conclusion}

Even when taking the limitations of this study into account, the results indicate that e-bikes have positive effects in terms of car trip replacement also in western countries with a distinct cycling culture, such as Denmark. We, however, found that these effects are smaller than effects found in 


\section{ACCEPTED MANUSCRIPT}

regions with no explicit tradition for cycling, such as North America or Australia. With increasing distribution of e-bikes, the overall environmental effects will also increase and this could be facilitated by interventions targeted at those potential users groups, in which the greatest effects are expected -- in our study the so-called enthusiastic e-bikers. While we provided examples how potential members of different segments could be targeted and showed that an attitudinal segmentation better differentiates with regard to e-bike use and satisfaction than a segmentation based on age, we suggest to enrich the segmentation by the inclusions of additional attitudinal factors, such as social norms and perceived constraints, which should lead more specific starting points for interventions.

\section{Acknowledgement}

The authors would like to acknowledge the financial and professional support by the Danish Road Safety Council (Rådet for Sikker Trafik). 


\section{ACCEPTED MANUSCRIPT}

References

Ajzen I. 1991. The Theory of Planned Behavior. Some unresolved issues. Organizational Behavior and Human Decision Processes, 50: 179--211.

Aldred, R, Jungnickel, K. 2014. Why culture matters for transport policy: the case of cycling in the UK. Journal of Transport Geography 34: 78--87.

Anable J. 2005. "Complacent Car Addicts" or "Aspiring Environmentalists": Identifying travel behaviour segments using attitude theory. Transport Policy 12: 65--78.

Anable J, Gatersleben B. 2005. All work and no play? The role of instrumental and affective factors in work and leisure journeys by different travel modes. Transportation Research, Part A 39:163--181.

Bamberg S, Fujii S, Friman M, Gärling T. 2011. Behaviour theory and soft transport policy measures. Transport Policy 18: 228--235.

Carstensen TA, Ebert A-K. 2012. Cycling cultures in Northern Europe: From "Golden Age" to "Renaissance.” In: Parkin J (ed.), Cycling and sustainability. Bingley: Emerald Group Publishing Limited, pp. 23--58.

Cherry C, Cervero R. 2007. Use characteristics and mode choice behavior of electric bike users in China. Transport Policy 14: 247--257.

Dill, J, McNeil, N. 2013. Four types of cyclists? Examination of typology for better understanding of bicycling behavior and potential. Transportation Research Record 2387: 129--138.

Dill J, Rose G. 2012. Electric bikes and transportation policy: Insights from early adopters. Journal of the Transportation Research Board 2314:1--6. Engelmoer W. 2012. The 


\section{ACCEPTED MANUSCRIPT}

E-bike: Opportunities for commuter traffic -- The potentials of using electricbicycles and -scooters in commuting traffic in relation to energy use, local emissions and the accessibility of a compact Dutch city. Master Thesis Energy and Environmental Sciences. University of Groningen: Groningen, The Netherlands.

Fietsberaad. 2013. One million e-cyclists. Retrieved from:

http://www.fietsberaad.nl/index.cfm?lang $=$ en\&section $=$ nieuws\&mode $=$ newsArticle\&repository = One+million+e-cyclists (10-02-2015).

Fyhri A, Fearnley N. 2015. Effects of e-bike on bicycle use and mode share. Transportation Research, Part D 36: 45--62.

Gatersleben B, Appleton KM. 2007. Contemplating cycling to work: Attitudes and perceptions in different stages of change. Transportation Research Part A: Policy and Practice 41: 302--312.

Hansen KB, Nielsen TAS. 2014. Exploring characteristics and motives of long distance commuter cyclists. Transport Policy 35: 57--63.

Haustein S \& Hunecke M. 2007. Reduced use of environmentally friendly modes of transportation caused by perceived mobility necessities: An extension of the Theory of Planned Behavior. Journal of Applied Social Psychology 37: 1856-1883.

Haustein S \& Hunecke M. 2013. Identifying target groups for environmentally sustainable transport: assessment of different segmentation approaches. Current Opinion in Environmental Sustainability 5(2): 197--204. 


\section{ACCEPTED MANUSCRIPT}

Haustein, S \& Møller, M. 2015. Sikkerhed på elcykel: trafikantfaktorer og trafiksituationer (Ebike safety: road user factors and trafic situations). Proceedings from the Annual Transport Conference (Trafikdage) at Aalborg University. Retrieved from: http://www.trafikdage.dk/papers_2015/334_SonjaHaustein.pdf

Haustein S, Siren A. 2015. Older people's mobility: Segments, factors, trends. Transport Reviews: A Transnational Transdisciplinary Journal, DOI: 10.1080/01441647.2015.1017867.

Heinen E, van Wee B, Maat K. 2010. Commuting by bicycle: An overview of the literature. Transport Reviews 30(1): 59--96.

Heinen E, Maat K, van Wee B. 2011. The role of attitudes toward characteristics of bicycle commuting on the choice to cycle to work over various distances. Transportation Research, Part D 16: 102--109.

Hildebrand E. 2003. Dimensions in elderly travel behaviour: A simplified activity-based model using lifestyle clusters. Transportation 30:285--306.

Hiselius LW, Svenssona Å. 2014. Could the increased use of e-bikes (pedelecs) in Sweden contribute to a more sustainable transport system? Selected papers of The 9th International Conference "ENVIRONMENTAL ENGINEERING”, 22--23 May 2014, Vilnius, Lithuania. Retrieved from: http://leidykla.vgtu.1t/conferences/ENVIRO_2014/Articles/3/119_Hiselius.pdf

Hunecke M, Schweer I. 2006. Einflussfaktoren der Alltagsmobilität -- Das Zusammenwirken von Raum, Verkehrsinfrastruktur, Lebensstil und Mobilitätseinstellungen [Determinants of daily mobility -- The interaction of space, traffic infrastructure, 


\section{ACCEPTED MANUSCRIPT}

life styles and mobility-related attitudes]. In: Beckmann KJ, Hesse M, Holz-Rau C, Hunecke M (eds.), StadtLeben -- Wohnen, Mobilität und Lebensstil. Wiesbaden: VS Verlag für Sozialwissenschaften, pp. 148--166.

Hunecke M, Haustein S, Böhler S, Grischkat S. 2010. Attitude-based target groups to reduce the ecological impact of daily mobility behavior. Environment and Behavior 42: 3--43.

Hunecke M, Haustein S, Grischkat S, Böhler, S. 2007. Psychological, sociodemographic, and infrastructural factors as determinants of ecological impact caused by mobility behavior. Journal of Environmental Psychology 27(4): 277--292.

Johnson M, Rose G. 2013. Electric bikes--cycling in the new world city: An investigation of Australian electric bicycle owners and the decision making process for purchase. In Proceedings of the 2013 Australasian Transport Research Forum, 2-4 October 2013, Brisbane, Australia. Retrieved 5.10.2015 from http://atrf.info/papers/2013/2013_johnson_rose.pdfLajunen, T, Summala, H. 2003. Can we trust self-reports of driving? Impression management on driver behaviour questionnaire responses. Transportation Research Part F: Traffic Psychology and Behaviour 6: 97--107.

Li Z, Wang W, Yang C, Ragland DR. 2013. Bicycle commuting market analysis using attitudinal market segmentation approach. Transportation Research, Part A 47: 56--68.

MacArthur J, Dill J, Person M. 2014. Electric bikes in North America: results of an online survey. Transportation Research Record 2468: 123--130.

Mercat N. 2013. Electric bicycles and the new frontier of urban cycling: Four years of e-bike development policies in Chambery. Paper presented at the VELO City 2013 


\section{ACCEPTED MANUSCRIPT}

Conference, June 2013, Vienna. Retrieved 5.10.2015 from: http://velocity2013.com/wp-content/uploads/20130613_NicolasMercat.pdf.

Nkurunziza, A, Zuidgeest, M, Van Maarseveen, M 2012. Identifying potential cycling market segments in Dar-es-Salaam, Tanzania. Habitat International, 36: 78--84.

Pooley CG, Horton D, Scheldeman G, Mullen C, Jones T, Tight M, Jopson A, Chisholm A. 2013. Policies for promoting walking and cycling in England: A view from the street. Transport Policy 27: 66--72.

Popovich N, Gordon E, Shao Z, Xing Y, Wang Y, Handy S. 2014. Experiences of electric bicycle users in the Sacramento, California area. Travel Behaviour and Society 1(2): 37--44.

Preissner CL, Kemming H, Wittowsky D. 2013. Einstellungsorientierte Akzeptanzanalyse zur Elektromobilität im Fahrradverkehr [Attitude-based analysis of acceptance with regard to electro-mobility in bicycle traffic]. ILS-Forschung 01/2013, ILS Institut für Landes- und Stadtentwicklungsforschung gGmbH, Dortmund 2013.

Pronello C, Camusso C. 2011.Travellers' profiles definition using statistical multivariate analysis of attitudinal variables. Journal of Transport Geography 19: 1294--1308.

Pucher J, Buehler R. 2008. Making cycling irresistible: Lessons from The Netherlands, Denmark and Germany. Transport Reviews 28: 495--528.

Rabi A, Nazelle AD. 2012. Benefits of shift from car to active transport. Transport Policy 19: $121--131$.

Roese, NJ, Vohs, KD 2012. Hindsight bias. Perspectives on Psychological Science 7(5): 411-426. 


\section{ACCEPTED MANUSCRIPT}

Rudolph F 2014. Promotion of pedelecs as a means to foster low-carbon mobility: scenarios for the German city of Wuppertal. Transportation Research Procedia, 4: 461--471.

Ryley T. 2006. Use of non-motorised modes and life stage in Edinburgh. Journal of Transport Geography 14: 367--375.

Salomon I, Ben-Akiva M. 1983.The use of the life-style concept in travel demand models. Environment and Planning A 15: 623--638.

Siegrist J, Wahrendorf M. 2009. Participation in socially productive activities and quality of life in early old age: Findings from SHARE. Journal of European Social Policy 19: $317--326$.

Statistics Denmark 2016. Data retrieved from http://www.statistikbanken.dk/ (25.02.2016)

Steg L. 2005: Car use: Lust and must. Instrumental, symbolic and affective motives for car use. Transportation Research, Part A 39: 147--162.

Taniguchi A, Grääs C, Friman M. 2014. Satisfaction with travel, goal achievement, and voluntary behavioural change. Transportation Research, Part F 26: 10--17.

VSSÖ (Verband der Sportartikelerzeuger und Sportausrüster Österreichs, 2015).

Presseinformation. Factbox zur Österreichischen Fahrrad-Industrie 2014. Retrieved 28.9.2015 from https://www.wko.at/Content.Node/branchen/oe/Handel-mit-Mode-undFreizeitartikeln/Sportartikelhandel/Facts-zur-Fahrrad-Industrie-und-Handel-2014.pdf Weinert JX, Ma C, Yang X, Cherry CR. 2007. Electric two-wheelers in China: Effect on travel behavior, mode shift, and user safety perceptions in a medium-sized city. Transportation Research Record 2038: 62--68. 


\section{ACCEPTED MANUSCRIPT}

Wolf A, Seebauer S 2014. Technology adoption of electric bicycles: A survey among early adopters. Transportation Research Part A: Policy and Practice, 69: 196--211.

Wu, X, Kumar, V, Quinlan, JR, Ghosh, J, Yang, Q, Motoda, H, McLachlan, GJ., Ng, A, Liu, B, Yu, PS, Zhou, Z-H, Steinbach, M, Hand, DJ, \& Steinberg, D. 2008. Top 10 algorithms in data mining. Knowledge and Information Systems, 14(1): 1--37. ZIV (Zweirad-Industrie-Verband, 2015). Pressemitteilung zum E-Bike Markt 2014. Zahlen -Daten -- Fakten zum Deutschen E-Bike-Markt 2014. Retrieved 28.9.2015 from http://zivzweirad.de/fileadmin/redakteure/Downloads/Marktdaten/PM_2015_18.03.2015_E-

Bikes.pdf 


\section{ACCEPTED MANUSCRIPT}

Table 1: Results of a principle component analysis based on attitudes and motivations for e-bike use

\begin{tabular}{|c|c|c|c|c|}
\hline & 1 & 2 & 3 & 4 \\
\hline Items & $\begin{array}{c}\text { Facilitate } \\
\text { cycling } \\
\text { (frequenc } \\
\text { y and } \\
\text { distance) }\end{array}$ & $\begin{array}{l}\text { Cycling } \\
\text { attitude }\end{array}$ & $\begin{array}{l}\text { E-bike } \\
\text { exciteme } \\
\text { nt }\end{array}$ & $\begin{array}{c}\text { Facilitate } \\
\text { cycling } \\
\text { (speed, } \\
\text { transport } \\
\text { of goods/ } \\
\text { children) }\end{array}$ \\
\hline $\begin{array}{l}\text { I bought an e-bike to cycle more often } \\
\text { or to start to cycle. }\end{array}$ & .821 & .091 & .054 & -.143 \\
\hline $\begin{array}{l}\text { I bought an e-bike to cover longer } \\
\text { distances. }\end{array}$ & .798 & .067 & .120 & .110 \\
\hline $\begin{array}{l}\text { I bought an e-bike to cycle longer } \\
\text { without getting exhausted. }\end{array}$ & .621 & .017 & .404 & .145 \\
\hline $\begin{array}{l}\text { I bought an e-bike because it is fun to } \\
\text { ride on an e-bike. }\end{array}$ & .465 & .252 & .448 & .095 \\
\hline I use the e-bike to get exercise. & .502 & .603 & -.007 & -.091 \\
\hline $\begin{array}{l}\text { I use the e-bike because it is good for } \\
\text { the environment. }\end{array}$ & .140 & .778 & .134 & .077 \\
\hline I use the e-bike because I like cycling. & .077 & .743 & .001 & .083 \\
\hline $\begin{array}{l}\text { I use the e-bike because it is cheaper } \\
\text { than other modes of transport. }\end{array}$ & -.074 & .743 & .179 & .215 \\
\hline $\begin{array}{l}\text { I find the higher speed and acceleration } \\
\text { on an e-bike exciting. }\end{array}$ & .134 & .074 & .788 & -.033 \\
\hline $\begin{array}{l}\text { I ride faster on an e-bike than on a } \\
\text { conventional bike. }\end{array}$ & .256 & .033 & .652 & -.127 \\
\hline $\begin{array}{l}\text { I experience that my higher speed } \\
\text { surprises other road users. }\end{array}$ & -.016 & .103 & .742 & .146 \\
\hline $\begin{array}{l}\text { I use the e-bike because it is faster than } \\
\text { other modes of transport. }\end{array}$ & -.014 & .133 & .013 & .854 \\
\hline $\begin{array}{l}\text { I use the e-bike because of practical } \\
\text { reasons (e.g. shopping, picking up } \\
\text { children). }\end{array}$ & .068 & .114 & .014 & .840 \\
\hline Cronbach's alpha (factors) & .72 & .73 & .68 & .69 \\
\hline
\end{tabular}




\section{ACCEPTED MANUSCRIPT}

Table 2: Group differences for different cluster solutions (2-5 clusters) with regard to e-bike frequency and distance

\begin{tabular}{|l|c|c|c|c|}
\hline & \multicolumn{2}{|c|}{ Cycling frequency } & \multicolumn{2}{c|}{ Cycling distance } \\
\hline Number of clusters & $\mathrm{X}^{2}$ & $p$ & $\mathrm{X}^{2}$ & $p$ \\
\hline 2 & 42.27 & .000 & .13 & .723 \\
\hline 3 & 49.73 & .000 & 8.85 & .012 \\
\hline 4 & 45.83 & .000 & 22.31 & .000 \\
\hline 5 & 44.49 & .000 & 27.50 & .000 \\
\hline
\end{tabular}




\section{ACCEPTED MANUSCRIPT}

Table 3: Comparison of the age and gender distribution of the sample with a weighted sample and with the adult population in Denmark

\begin{tabular}{|c|c|c|c|}
\hline & $\begin{array}{c}\text { E-bike users } \\
\text { (sample) }\end{array}$ & $\begin{array}{c}\text { E-bike users (weighted } \\
\text { sample) }\end{array}$ & $\begin{array}{l}\text { Adult population in } \\
\text { Denmark }^{\mathrm{a}}\end{array}$ \\
\hline \multicolumn{4}{|l|}{ Age } \\
\hline 18--29 & $1.9 \%$ & $8.0 \%$ & $19.4 \%$ \\
\hline $30--39$ & $8.5 \%$ & $8.9 \%$ & $15.1 \%$ \\
\hline $40--49$ & $13.6 \%$ & $15.1 \%$ & $17.9 \%$ \\
\hline 50--59 & $26.8 \%$ & $22.1 \%$ & $16.7 \%$ \\
\hline 60--69 & $36.9 \%$ & $24.9 \%$ & $15.3 \%$ \\
\hline $70+$ & $12.2 \%$ & $20.9 \%$ & $15.6 \%$ \\
\hline \multicolumn{4}{|l|}{ Gender } \\
\hline women & $51.0 \%$ & $56.0 \%$ & $51.0 \%$ \\
\hline \multicolumn{4}{|l|}{$\begin{array}{l}\text { Educatio } \\
\mathrm{n}\end{array}$} \\
\hline $\begin{array}{r}\text { basic } \\
\text { education } \\
\text { only } \\
\end{array}$ & $9.2 \%$ & $24.1 \%$ & $28.5 \%$ \\
\hline $\begin{array}{r}\text { university } \\
\text { degree } \\
\text { (higher } \\
\text { than }\end{array}$ & & & \\
\hline bachelor) & $21.8 \%$ & $14.7 \%$ & $8.5 \%$ \\
\hline
\end{tabular}

${ }^{\mathrm{a}}$ Source: Statistics Denmark (2016); age and gender based on the whole population in Denmark above 17 years of age in the year 2015; education based on the population aged 15-69. 


\section{ACCEPTED MANUSCRIPT}

Table 4: Means and standard deviations for the clusters with regard to the different factors

\begin{tabular}{|l|c|c|c|c|c|c|c|c|}
\hline & \multicolumn{2}{|c|}{$\begin{array}{c}\text { Facilitate cycling (speed, } \\
\text { transport of goods/children) }\end{array}$} & \multicolumn{2}{|c|}{$\begin{array}{c}\text { Cycling } \\
\text { attitude }\end{array}$} & \multicolumn{2}{|c|}{$\begin{array}{c}\text { E-bike } \\
\text { excitement }\end{array}$} & \multicolumn{2}{|c|}{$\begin{array}{c}\text { Facilitate cycling } \\
\text { frequency and } \\
\text { distance) }\end{array}$} \\
\hline Clusters & $M$ & $S D$ & $M$ & $S D$ & $M$ & $S D$ & $M$ & $S D$ \\
\hline $\begin{array}{l}\text { Enthusiastic e- } \\
\text { biker }(n=201)\end{array}$ & 3.90 & 0.73 & 4.29 & 0.61 & 4.31 & 0.55 & 4.61 & 0.48 \\
\hline $\begin{array}{l}\text { Utilitarian e- } \\
\text { biker }(n=104)\end{array}$ & 3.44 & 0.89 & 3.56 & 0.86 & 3.36 & 0.75 & 2.84 & 0.91 \\
\hline $\begin{array}{l}\text { Recreational e- } \\
\text { biker }(n=122)\end{array}$ & 1.59 & 0.62 & 3.74 & 0.94 & 4.00 & 0.75 & 4.23 & 0.65 \\
\hline ANOVA & \multicolumn{2}{|c|}{$F(2,424)=255.44^{* * *}$} & $\begin{array}{c}F(2,426)= \\
36.22^{* * *}\end{array}$ & $\begin{array}{c}F(2,426)= \\
70.94 * * *\end{array}$ & $F(2,424)=376.82^{* * * *}$ \\
\hline
\end{tabular}

$p<.001$ 


\section{ACCEPTED MANUSCRIPT}

Table 5: Cycling frequency by e-bike and conventional bike for e-bike segments and age groups

\begin{tabular}{|c|c|c|c|c|c|c|c|c|}
\hline & & $\frac{\lambda}{\bar{\pi}}$ & 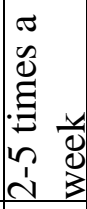 & $\begin{array}{l}\frac{2}{2} \\
\frac{d}{3} \\
3\end{array}$ & 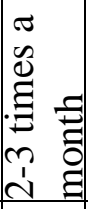 & & \multicolumn{2}{|c|}{ 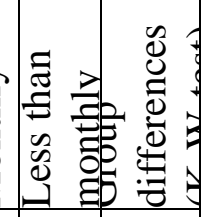 } \\
\hline Cycling frequency on... & $\begin{array}{l}\text { Segments (\% within } \\
\text { segment) }\end{array}$ & & & & & & & \\
\hline $\begin{array}{l}\text { conventional bike -- before e- } \\
\text { bike access }\end{array}$ & enthusiastic e-biker & $\begin{array}{r}20 . \\
6 \\
\end{array}$ & $\begin{array}{r}26 . \\
1\end{array}$ & $\begin{array}{r}10 . \\
1 \\
\end{array}$ & $\begin{array}{r}4 . \\
14 \\
\end{array}$ & $\begin{array}{r}7 . \\
5 \\
\end{array}$ & $\begin{array}{r}21 . \\
6\end{array}$ & \\
\hline & utilitarian e-biker & $\begin{array}{r}37 . \\
6\end{array}$ & $\begin{array}{r}29 . \\
7\end{array}$ & 6.9 & 5.9 & $\begin{array}{c}5 . \\
9 \\
\end{array}$ & $\begin{array}{r}13 . \\
9\end{array}$ & \\
\hline & recreational e-biker & 7.4 & $\begin{array}{r}15 . \\
7 \\
\end{array}$ & 9.9 & $\begin{array}{r}13 . \\
2 \\
\end{array}$ & $\begin{array}{r}9 . \\
1 \\
\end{array}$ & $\begin{array}{r}44 . \\
6 \\
\end{array}$ & $\begin{array}{r}0.00 \\
0 \\
\end{array}$ \\
\hline $\begin{array}{l}\text { conventional bike -- after e-bike } \\
\text { access }\end{array}$ & enthusiastic e-biker & 9.0 & $\begin{array}{r}10 . \\
4\end{array}$ & 8.5 & 5.5 & $\begin{array}{r}7 . \\
5 \\
\end{array}$ & $\begin{array}{r}59 . \\
2\end{array}$ & \\
\hline & utilitarian e-biker & $\begin{array}{r}17 . \\
5\end{array}$ & $\begin{array}{r}22 . \\
3 \\
\end{array}$ & 8.7 & 5.8 & $\begin{array}{r}4 . \\
9 \\
\end{array}$ & $\begin{array}{r}40 . \\
8 \\
\end{array}$ & \\
\hline & recreational e-biker & 3.4 & 9.2 & 5.9 & 8.4 & $\begin{array}{r}5 . \\
9 \\
\end{array}$ & $\begin{array}{r}67 . \\
2 \\
\end{array}$ & $\begin{array}{r}0.00 \\
0 \\
\end{array}$ \\
\hline e-bike & enthusiastic e-biker & $\begin{array}{r}37 . \\
3\end{array}$ & $\begin{array}{r}46 . \\
3 \\
\end{array}$ & 9.0 & 4.5 & $\begin{array}{r}1 . \\
5 \\
\end{array}$ & 1.5 & \\
\hline & utilitarian e-biker & $\begin{array}{r}34 . \\
0\end{array}$ & $\begin{array}{r}43 . \\
7 \\
\end{array}$ & $\begin{array}{r}11 . \\
7 \\
\end{array}$ & 5.8 & $\begin{array}{r}3 . \\
9 \\
\end{array}$ & 1.0 & \\
\hline & recreational e-biker & 8.3 & $\begin{array}{r}47 . \\
1\end{array}$ & $\begin{array}{r}17 . \\
4 \\
\end{array}$ & $\begin{array}{r}16 . \\
5 \\
\end{array}$ & $\begin{array}{r}6 . \\
6 \\
\end{array}$ & 4.1 & $\begin{array}{r}0.00 \\
0 \\
\end{array}$ \\
\hline & $\begin{array}{l}\text { Age groups (\% within age } \\
\text { group) }\end{array}$ & & & & & & & \\
\hline $\begin{array}{l}\text { conventional bike -- before e- } \\
\text { bike access }\end{array}$ & $19--35$ & $\begin{array}{r}40 . \\
6 \\
\end{array}$ & $\begin{array}{r}28 . \\
1 \\
\end{array}$ & 6.3 & 6.3 & $\begin{array}{r}6 . \\
3 \\
\end{array}$ & $\begin{array}{r}12 . \\
5\end{array}$ & \\
\hline & $36--55$ & $\begin{array}{r}21 . \\
8\end{array}$ & $\begin{array}{r}18 . \\
5 \\
\end{array}$ & 9.7 & $\begin{array}{r}11 . \\
3 \\
\end{array}$ & $\begin{array}{r}5 . \\
6 \\
\end{array}$ & $\begin{array}{r}33 . \\
1 \\
\end{array}$ & \\
\hline & $56--65$ & $\begin{array}{r}19 . \\
9\end{array}$ & $\begin{array}{r}21 . \\
7 \\
\end{array}$ & 9.3 & $\begin{array}{r}13 . \\
7 \\
\end{array}$ & $\begin{array}{r}8 . \\
7 \\
\end{array}$ & $\begin{array}{r}26 . \\
7 \\
\end{array}$ & \\
\hline & $66+$ & $\begin{array}{r}14 . \\
7\end{array}$ & $\begin{array}{r}32 . \\
4\end{array}$ & 9.8 & $\begin{array}{r}11 . \\
8\end{array}$ & $\begin{array}{r}8 . \\
8\end{array}$ & $\begin{array}{r}22 . \\
5\end{array}$ & $\begin{array}{r}0.01 \\
7 \\
\end{array}$ \\
\hline $\begin{array}{l}\text { conventional bike -- after e-bike } \\
\text { access }\end{array}$ & $19--35$ & 6.3 & $\begin{array}{r}28 . \\
1\end{array}$ & $\begin{array}{r}12 . \\
5 \\
\end{array}$ & 6.3 & $\begin{array}{r}9 . \\
4 \\
\end{array}$ & $\begin{array}{r}37 . \\
5 \\
\end{array}$ & \\
\hline & $36--55$ & $\begin{array}{r}11 . \\
9\end{array}$ & $\begin{array}{r}12 . \\
7\end{array}$ & 7.1 & 4.8 & $\begin{array}{r}5 . \\
6 \\
\end{array}$ & $\begin{array}{r}57 . \\
9 \\
\end{array}$ & \\
\hline & $56--65$ & 8.1 & 9.3 & 6.8 & 9.3 & $\begin{array}{c}5 . \\
6\end{array}$ & $\begin{array}{r}60 . \\
9\end{array}$ & \\
\hline
\end{tabular}




\section{ACCEPTED MANUSCRIPT}

\begin{tabular}{|c|c|c|c|c|c|c|c|c|}
\hline & $66+$ & 9.8 & $\begin{array}{r}14 . \\
7\end{array}$ & 8.8 & 3.9 & $\begin{array}{r}6 . \\
9\end{array}$ & $\begin{array}{r}55 . \\
9\end{array}$ & $\begin{array}{r}0.14 \\
7\end{array}$ \\
\hline \multirow[t]{4}{*}{ e-bike } & $19--35$ & $\begin{array}{r}34 . \\
4\end{array}$ & $\begin{array}{r}43 . \\
8\end{array}$ & $\begin{array}{r}12 . \\
5\end{array}$ & 6.3 & $\begin{array}{r}0 . \\
0\end{array}$ & 3.1 & \\
\hline & $36--55$ & $\begin{array}{r}31 . \\
3\end{array}$ & $\begin{array}{r}43 . \\
0\end{array}$ & 9.4 & 9.4 & $\begin{array}{r}3 . \\
9\end{array}$ & 3.1 & \\
\hline & $56--65$ & $\begin{array}{r}26 . \\
7\end{array}$ & $\begin{array}{r}48 . \\
4\end{array}$ & $\begin{array}{r}13 . \\
0\end{array}$ & 7.5 & $\begin{array}{r}3 . \\
1\end{array}$ & 1.2 & \\
\hline & $66+$ & $\begin{array}{r}25 . \\
5\end{array}$ & $\begin{array}{r}46 . \\
1\end{array}$ & $\begin{array}{r}13 . \\
7\end{array}$ & 8.8 & $\begin{array}{r}4 . \\
9\end{array}$ & 1.0 & $\begin{array}{r}0.73 \\
7\end{array}$ \\
\hline
\end{tabular}




\section{ACCEPTED MANUSCRIPT}

Table 6: Distances covered by e-bike and conventional bike for e-bike segments and age groups

\begin{tabular}{|c|c|c|c|c|c|c|c|c|}
\hline & & $\begin{array}{l}\underset{\Xi}{\Xi} \\
\stackrel{\Lambda}{\Lambda} \\
\wedge\end{array}$ & $\begin{array}{l}\tilde{y} \\
0 \\
0 \\
i \\
0\end{array}$ & $\left|\begin{array}{c}\tilde{g} \\
0 \\
0 \\
\vdots \\
n \\
n\end{array}\right|$ & $\begin{array}{c}\tilde{g} \\
\frac{a}{n} \\
\dot{m}\end{array}$ & $\frac{\xi}{\tilde{v}}$ & 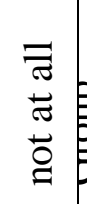 & 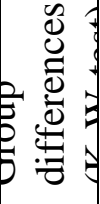 \\
\hline Cycling distance on... & $\begin{array}{l}\begin{array}{l}\text { Segments } \\
\text { (\% within segment) }\end{array} \\
\end{array}$ & & & & & & & \\
\hline \multirow[t]{3}{*}{$\begin{array}{l}\text { conventional bike -- before e- } \\
\text { bike access }\end{array}$} & enthusiastic e-biker & 1.1 & 9.9 & $\begin{array}{r}21 . \\
0\end{array}$ & $\begin{array}{r}35 . \\
9\end{array}$ & $\begin{array}{r}28 . \\
2\end{array}$ & 3.9 & \\
\hline & utilitarian e-biker & 7.4 & $\begin{array}{r}19 . \\
1\end{array}$ & $\begin{array}{r}26 . \\
6 \\
\end{array}$ & $\begin{array}{r}21 . \\
3\end{array}$ & $\begin{array}{r}19 . \\
1 \\
\end{array}$ & 6.4 & \\
\hline & recreational e-biker & 3.1 & 9.2 & $\begin{array}{r}20 . \\
4 \\
\end{array}$ & $\begin{array}{r}31 . \\
6\end{array}$ & $\begin{array}{r}29 . \\
6\end{array}$ & 6.1 & $\begin{array}{r}0.00 \\
6\end{array}$ \\
\hline \multirow[t]{3}{*}{$\begin{array}{l}\text { conventional bike -- after e-bike } \\
\text { access }\end{array}$} & enthusiastic e-biker & 1.1 & 3.7 & 7.0 & $\begin{array}{r}13 . \\
4 \\
\end{array}$ & $\begin{array}{r}23 . \\
5 \\
\end{array}$ & $\begin{array}{r}51 . \\
3 \\
\end{array}$ & \\
\hline & utilitarian e-biker & 6.1 & $\begin{array}{r}14 . \\
1\end{array}$ & $\begin{array}{r}12 . \\
1\end{array}$ & $\begin{array}{r}13 . \\
1\end{array}$ & $\begin{array}{r}21 . \\
2\end{array}$ & $\begin{array}{r}33 . \\
3\end{array}$ & \\
\hline & recreational e-biker & 0.9 & 3.4 & 5.2 & $\begin{array}{r}12 . \\
9 \\
\end{array}$ & $\begin{array}{r}22 . \\
4 \\
\end{array}$ & $\begin{array}{r}55 . \\
2 \\
\end{array}$ & $\begin{array}{r}0.00 \\
0 \\
\end{array}$ \\
\hline \multirow[t]{4}{*}{ e-bike } & enthusiastic e-biker & $\begin{array}{r}14 . \\
1\end{array}$ & $\begin{array}{r}34 . \\
3\end{array}$ & $\begin{array}{r}26 . \\
8 \\
\end{array}$ & $\begin{array}{r}17 . \\
2\end{array}$ & 7.1 & 0.5 & \\
\hline & utilitarian e-biker & 7.9 & $\begin{array}{r}25 . \\
\end{array}$ & $\begin{array}{r}28 . \\
7 \\
\end{array}$ & $\begin{array}{r}24 . \\
8\end{array}$ & $\begin{array}{r}12 . \\
9 \\
\end{array}$ & 0.0 & \\
\hline & recreational e-biker & $\begin{array}{r}21 . \\
2\end{array}$ & $\begin{array}{r}26 . \\
3\end{array}$ & $\begin{array}{r}22 . \\
9\end{array}$ & $\begin{array}{r}19 . \\
5\end{array}$ & 7.6 & 2.5 & \begin{tabular}{|r|}
0.01 \\
8
\end{tabular} \\
\hline & $\begin{array}{l}\text { Age groups (\% within age } \\
\text { group) }\end{array}$ & & & & & & & \\
\hline \multirow[t]{4}{*}{$\begin{array}{l}\text { conventional bike -- before e- } \\
\text { bike access }\end{array}$} & $19--35$ & 0.0 & $\begin{array}{r}10 . \\
0\end{array}$ & $\begin{array}{r}30 . \\
0 \\
\end{array}$ & $\begin{array}{r}33 . \\
3 \\
\end{array}$ & $\begin{array}{r}20 . \\
0 \\
\end{array}$ & 6.7 & \\
\hline & $36--55$ & 7.8 & $\begin{array}{r}12 . \\
7\end{array}$ & $\begin{array}{r}21 . \\
6 \\
\end{array}$ & $\begin{array}{r}31 . \\
4 \\
\end{array}$ & $\begin{array}{r}17 . \\
6 \\
\end{array}$ & 8.8 & \\
\hline & $56--65$ & 2.1 & $\begin{array}{r}16 . \\
9\end{array}$ & $\begin{array}{r}18 . \\
3 \\
\end{array}$ & $\begin{array}{r}31 . \\
7\end{array}$ & $\begin{array}{r}27 . \\
5\end{array}$ & 3.5 & \\
\hline & $66+$ & 0.0 & 5.2 & $\begin{array}{r}26 . \\
8 \\
\end{array}$ & $\begin{array}{r}29 . \\
9 \\
\end{array}$ & $\begin{array}{r}35 . \\
1 \\
\end{array}$ & 3.1 & $\begin{array}{r}0.18 \\
5 \\
\end{array}$ \\
\hline \multirow[t]{3}{*}{$\begin{array}{l}\text { conventional bike -- after e-bike } \\
\text { access }\end{array}$} & $19--35$ & 0.0 & $\begin{array}{r}10 . \\
0\end{array}$ & $\begin{array}{r}10 . \\
0\end{array}$ & $\begin{array}{r}13 . \\
3\end{array}$ & $\begin{array}{r}23 . \\
3 \\
\end{array}$ & $\begin{array}{r}43 . \\
3\end{array}$ & \\
\hline & $36--55$ & 6.5 & 5.7 & 9.8 & $\begin{array}{r}10 . \\
6 \\
\end{array}$ & $\begin{array}{r}20 . \\
3 \\
\end{array}$ & $\begin{array}{r}47 . \\
2 \\
\end{array}$ & \\
\hline & $56--65$ & 0.7 & 6.6 & 5.3 & $\begin{array}{r}13 . \\
2\end{array}$ & $\begin{array}{r}20 . \\
4 \\
\end{array}$ & $\begin{array}{r}53 . \\
9 \\
\end{array}$ & \\
\hline
\end{tabular}




\section{ACCEPTED MANUSCRIPT}

\begin{tabular}{|c|c|c|c|c|c|c|c|c|}
\hline & $66+$ & 0.0 & 4.2 & 8.4 & $\begin{array}{r}16 \\
8\end{array}$ & $\begin{array}{r}29 . \\
5\end{array}$ & \begin{tabular}{|r|}
41. \\
1
\end{tabular} & $\begin{array}{r}0.31 \\
0\end{array}$ \\
\hline e-bike & 19--35 & 9.7 & $\begin{array}{r}45 . \\
2 \\
\end{array}$ & $\begin{array}{r}16 . \\
1 \\
\end{array}$ & $\begin{array}{r}16 . \\
1\end{array}$ & $\begin{array}{r}12 . \\
9 \\
\end{array}$ & 0.0 & \\
\hline & $36--55$ & $\begin{array}{r}23 . \\
0\end{array}$ & $\begin{array}{r}31 . \\
0 \\
\end{array}$ & \begin{tabular}{|r}
26. \\
2 \\
\end{tabular} & $\begin{array}{r}15 . \\
9 \\
\end{array}$ & 2.4 & 1.6 & \\
\hline & $56--65$ & $\begin{array}{r}13 . \\
3\end{array}$ & $\begin{array}{r}29 . \\
7\end{array}$ & $\begin{array}{r}24 . \\
7\end{array}$ & $\begin{array}{r}21 . \\
5\end{array}$ & $\begin{array}{r}10 . \\
1\end{array}$ & 0.6 & \\
\hline & $66+$ & 8.0 & $\begin{array}{r}25 . \\
0\end{array}$ & $\begin{array}{r}32 . \\
0\end{array}$ & $\begin{array}{r}22 . \\
0\end{array}$ & $\begin{array}{r}12 . \\
0\end{array}$ & 1.0 & $\begin{array}{r}0.00 \\
2\end{array}$ \\
\hline
\end{tabular}




\section{ACCEPTED MANUSCRIPT}

Table 7: Agreement to use of e-bike as replacement of trips by other modes by clusters

\begin{tabular}{|c|c|c|c|c|}
\hline Replaced mode & Cluster & $M$ & $S D$ & ANOVA \\
\hline \multirow[t]{3}{*}{ conventional bike } & enthusiastic e-biker & 3.86 & 1.28 & \multirow[b]{3}{*}{$F(2,416)=11.49^{* * * *}$} \\
\hline & utilitarian e-biker & 3.09 & 1.43 & \\
\hline & recreational e-biker & 3.42 & 1.48 & \\
\hline \multirow[t]{3}{*}{ walking } & enthusiastic e-biker & 3.07 & 1.38 & \multirow[b]{3}{*}{$F(2,419)=8.63^{* * *}$} \\
\hline & utilitarian e-biker & 2.39 & 1.35 & \\
\hline & recreational e-biker & 2.69 & 1.44 & \\
\hline \multirow[t]{3}{*}{ bus } & enthusiastic e-biker & 3.47 & 1.42 & \multirow[b]{3}{*}{$F(2,414)=20.49^{* * * *}$} \\
\hline & utilitarian e-biker & 2.81 & 1.52 & \\
\hline & recreational e-biker & 2.40 & 1.51 & \\
\hline \multirow[t]{3}{*}{ train/metro } & enthusiastic e-biker & 2.71 & 1.49 & \multirow[b]{3}{*}{$F(2,397)=12.74^{* * * *}$} \\
\hline & utilitarian e-biker & 2.17 & 1.36 & \\
\hline & recreational e-biker & 1.90 & 1.27 & \\
\hline \multirow[t]{3}{*}{ car } & enthusiastic e-biker & 3.58 & 1.18 & \multirow[b]{3}{*}{$F(2,402)=9.44^{* * *}$} \\
\hline & utilitarian e-biker & 2.89 & 1.46 & \\
\hline & recreational e-biker & 3.18 & 1.41 & \\
\hline
\end{tabular}




\section{ACCEPTED MANUSCRIPT}

Table 8: Differences between e-bike segments in demographic variables

\begin{tabular}{|c|c|c|c|c|c|c|}
\hline & & $\begin{array}{c}\text { enthusiasti } \\
\text { c } \\
\text { e-biker }\end{array}$ & $\begin{array}{l}\text { utilitarian e- } \\
\text { biker }\end{array}$ & $\begin{array}{l}\text { recreational e- } \\
\text { biker }\end{array}$ & all & $\begin{array}{l}\mathrm{Chi}^{2} \\
\text {-test }\end{array}$ \\
\hline \multirow[t]{4}{*}{ Age } & $19--35$ & $9.0 \%$ & $9.6 \%$ & $4.1 \%$ & $7.8 \%$ & \\
\hline & $36--55$ & $25.1 \%$ & $39.4 \%$ & $31.1 \%$ & $\begin{array}{r}30.4 \\
\%\end{array}$ & \\
\hline & $56--65$ & $40.2 \%$ & $33.7 \%$ & $37.7 \%$ & $\begin{array}{r}37.9 \\
\%\end{array}$ & \\
\hline & $66+$ & $25.6 \%$ & $17.3 \%$ & $27.0 \%$ & $\begin{array}{r}24.0 \\
\%\end{array}$ & .087 \\
\hline \multirow[t]{2}{*}{ Gender } & Women & $56.7 \%$ & $41.3 \%$ & $49.2 \%$ & $\begin{array}{r}50.8 \\
\% \\
\end{array}$ & \\
\hline & Men & $43.3 \%$ & $58.7 \%$ & $50.8 \%$ & $\begin{array}{r}49.2 \\
\% \\
\end{array}$ & .036 \\
\hline \multirow[t]{2}{*}{$\begin{array}{l}\text { Educatio } \\
\mathrm{n}\end{array}$} & $\begin{array}{l}\text { basic education } \\
\text { only }\end{array}$ & $5.6 \%$ & $12.5 \%$ & $12.5 \%$ & $9.2 \%$ & .049 \\
\hline & university degree & $23.7 \%$ & $22.1 \%$ & $18.3 \%$ & $\begin{array}{r}21.8 \\
\%\end{array}$ & .525 \\
\hline Region & Copenhagen & $14.9 \%$ & $20.2 \%$ & $8.2 \%$ & $\begin{array}{r}14.3 \\
\% \\
\end{array}$ & .350 \\
\hline
\end{tabular}




\section{ACCEPTED MANUSCRIPT}
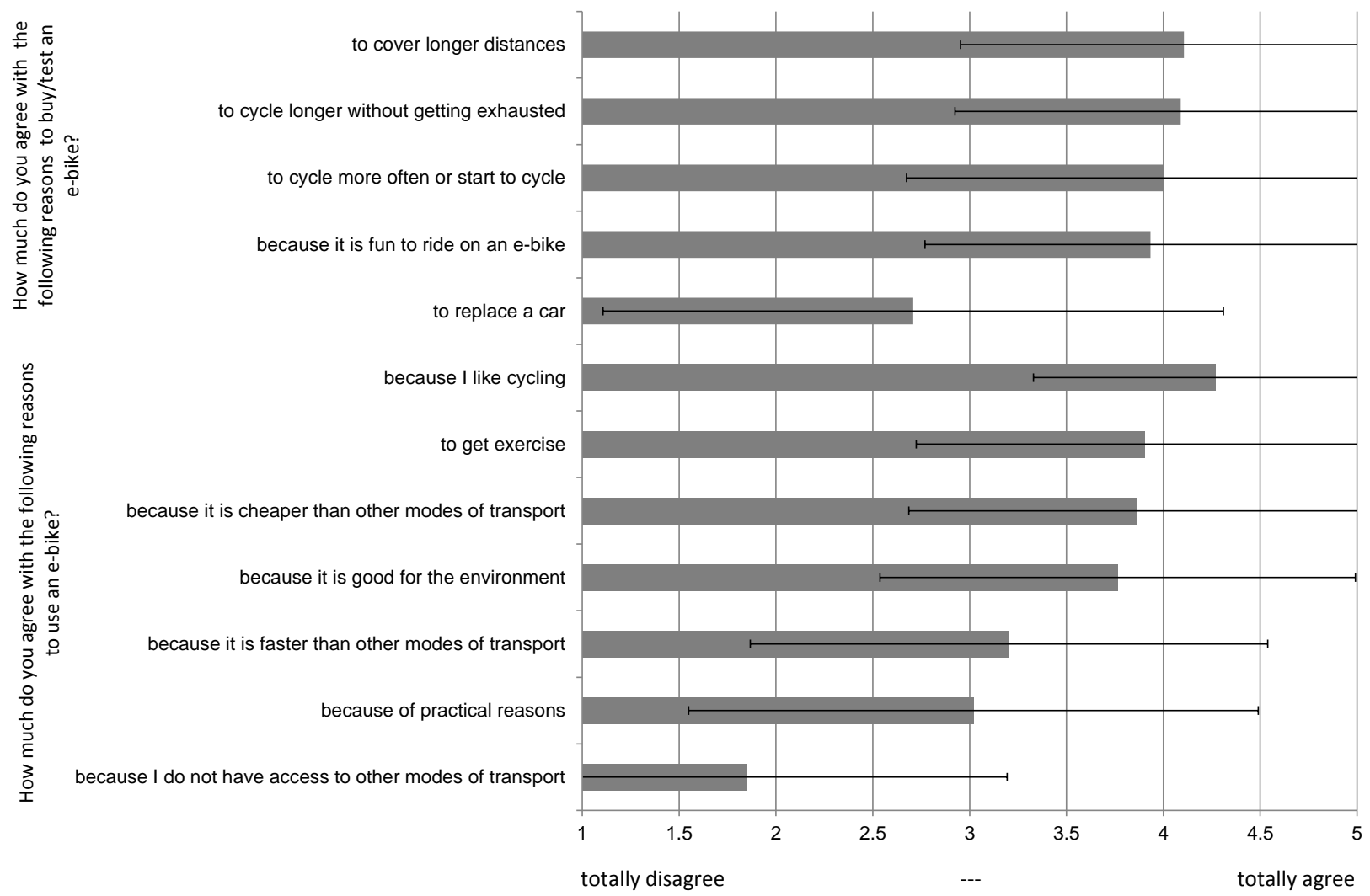

Figure 1: Motivations to buy/test and to use an e-bike (means and standard deviations) 